\title{
Prevalence of Endoparasites in Faecal Samples of Cracids Bred in Captivity at the Parque Dois Irmãos, Recife, Pernambuco, Brazil
}

\author{
A.L.B. CUNHA, F.S. MENDONÇA, R.A. OLIVEIRA, L. BARATELLA- EVÊNCIO, \\ R.M. OLIVEIRA-FILHO, R.S. SIMÕES, M.J. SIMÕES, J. EVÊNCIO-NETO
}

Department of Animal Morphology and Physiology, Federal Rural University of Pernambuco, Brazil

\author{
Received July 19, 2007
}

Accepted June 11, 2008

\begin{abstract}
Cunha A. L.B., F. S. Mendonça, R. A. Oliveira, L. Baratella- Evêncio, R. M. OliveiraFilho, R. S. Simões, M. J. Simões, J. Evêncio-Neto: Prevalence of Endoparasites in Faecal Samples of Cracids Bred in Captivity at the Parque Dois Irmãos, Recife, Pernambuco, Brazil. Acta Vet. Brno 2008, 77: 387-392.

Among the many problems arising from poor sanitation that can affect wild birds maintained in captivity, parasitic afflictions are among the most frequent, and their effects can range from subclinical infections to death. Some of the most common cases involve endoparasites, principally if the species under consideration exists at a high population density. This being so, the aim of the current work was to report on the prevalence of endoparasites in faecal samples from cracids (curassows and allies) bred in captivity at the Parque Dois Irmãos, Recife, Pernambuco state in Brazil. To do this, faecal and sand samples were collected from the enclosures of birds of the family Cracidae belonging to the collection from the Parque Dois Irmãos, which originated from private collections from the Metropolitan Region and Forest Zone of the State of Pernambuco. Four lots of faecal and sand samples were collected over a 60-day period, giving a total of 84 faecal samples from 58 individuals of 21 species of cracids. The material collected was submitted for coproparasitological tests using the right method and spontaneous sedimentation. The results obtained were positive for Strongyloides sp., Ascaridia sp., Capillaria sp. and cysts of Entamoeba coli, as well as eggs belonging to the superfamily Strongyloidea.
\end{abstract}

Aves, parasites, nematodes, Cracidae

The family Cracidae comprises the large Galliformes of South America. The Brazilian cracids include chachalacas, guans, piping-guans and curassows and are grouped into six genera: Ortalis, Penelope, Pipile, Crax, Mitu and Nothocrax. It is considered that there are approximately 50 species of cracids, of which 25 occur in Brazil (Evêncio-Neto 2006).

Parasitism in these birds has implications not only for their ecology and evolution but also their conservation (Couto 1997) because it is one of the commonest problems affecting wild birds as a result of their often having limited or no access to clean water. Parasitism can cause conditions ranging from sub-clinical infections to death (Freitas et al. 2002), especially in the case of infection by very common endoparasites, which often occurs when animals are at a high population density (Barnes 1986). Practically all groups of animals, including the curassows and their allies, are vulnerable to parasitic infection, some parasites being host-specific (Krantz 1970).

Endoparasitic infection is common in birds kept in captivity. Freitas et al. (2002) reported a high diversity of gastrointestinal parasites in captive-bred birds from the state of Pernambuco. According to these authors, roundworms and protozoans, among them Capillaria sp., Ascaridia sp., Trichostrongylus sp., Strongyloides sp., Spiruroidea, Entamoeba coli and coccidia, were found to be prevalent in $50.9 \%$ of samples from the family Cracidae.

Another important factor related to parasitism in wild bird species kept in captivity is 
the fact that the breeding of individuals from different geographical regions increases the likelihood of the emergence of malignant parasitic infestations (Benez 2004). According to this reasoning, a given coevolutive parasite-host relationship may be relatively inoffensive. However, the parasite might be highly pathogenic to animals brought in from another locality because such animals may be considered non-co-evolutive hosts (Ritchie et al. 1994).

This being the case, the identification of endoparasites if or when they occur is of fundamental importance when reviewing appropriate hygiene protocols during the captivebreeding of wildlife. Apart from this, there are few papers describing the endoparasites of Brazilian wild bird species in the national and international scientific literature. Knowing the importance of diagnosing these infections, the objective of this work was to report the prevalence of endoparasites in faecal samples from cracids bred in captivity at the Parque Dois Irmãos, Recife, Pernambuco, which in turn had come from various private collections within the state of Pernambuco.

\section{Materials and Methods}

Birds of the family Cracidae originating from private collections from a variety of different regions within the state of Pernambuco were studied. The animals were kept in quarantine and then incorporated into the collection at the Parque Dois Irmãos (PDI) in the Dois Irmãos ecological reserve in the district of Dois Irmãos which lies to the northwest of the city of Recife. PDI covers an area of 384.4 ha and lies at $\mathrm{km} 69$ parallel to the northbound highway number BR-101. The zoo occupies an area of 14 ha (Machado et al. 1998).

The birds were assessed clinically and selected so that samples could be obtained for coproparasitological tests. For these, faecal samples were collected using a spatula and placed into a plastic container. This procedure was repeated with soil samples taken from various points in the pens. Four collections of faecal samples and one of soil were made over a period of 60 days. The samples were analysed using the direct method of Scholtens et al. (1982), and that of spontaneous sedimentation of Greve et al. (1978).

The samples were sent to the Laboratory of Parasitology in the Department of Biology at the Federal Rural University of Pernambuco (Laboratório de Parasitologia, Departamento de Biologia, Universidade Federal Rural de Pernambuco). The different genera of parasites were identified according to morphological criteria. A total of $84(\mathrm{~T}=84)$ faecal samples from 58 birds $(\mathrm{n}=58)$ representing 21 species of Cracid were examined: Ortalis guttata $(\mathrm{n}=3)$, Penelope superciliaris $(\mathrm{n}=4)$, P. obscura $(\mathrm{n}=2), P$. jacquacu $(\mathrm{n}=1)$, P. ochrogaster $(\mathrm{n}=1)$, Pipile pipile cujubi $(\mathrm{n}=1)$, P. pipile cumanensis $(\mathrm{n}=1)$, P. jacutinga $(\mathrm{n}=1), 3$ Crax pauxi $(\mathrm{n}=3)$, C. fasciolata fasciolata $(\mathrm{n}=10), C$. fasciolata pinima $(\mathrm{n}=3), C$. alector alector $(\mathrm{n}=2), C$. alector erythrognatha $(\mathrm{n}=3), C$. blumenbachii $(\mathrm{n}=1)$, C. daubentoni $(\mathrm{n}=3)$, C. rubra rubra $(\mathrm{n}=2)$, C. globulosa $(\mathrm{n}=5)$, C. alberti $(\mathrm{n}=2)$, Mitu tomentosa $(\mathrm{n}=2)$, M. tuberosa $(\mathrm{n}=5)$, and Nothocrax urumutum $(\mathrm{n}=3)$.

\section{Results and Discussion}

Out of the samples analyzed, $4.7 \%$ were of the genus Ortalis, $19.0 \%$ of the genus Penelope, $14.2 \%$ of the genus Pipile, $47.6 \%$ of the genus Crax, $9.5 \%$ of the genus Mitu and $4.7 \%$ of the genus Nothocrax. Among the species analysed, the coproparasitological tests tested positive for Strongyloides sp., Ascaridia sp., Capillaria sp. and the cysts of Entamoeba coli, apart from eggs belonging to the superfamily Strongyloidae (Table 1). Similar results to those presented here were obtained by Freitas et al. (2002). They found in the family Cracidae a 50.9\% prevalence of roundworms and protozoans, among which were Capillaria sp., Ascaridia sp., Trichostrongylus sp., Strongyloides sp., Spiruroidea, Entamoeba coli and coccidia.

It was observed that endoparasite prevalence was the highest in birds of the genus Pipile (Table 2) as reflected by the high percentage of infection with Strongyloides sp. (50\% prevalence - Table 3). Also noteworthy was the 50\% prevalence of Strongyloidea eggs and $50 \%$ Strongyloidea eggs in birds of the genus Ortalis. The prevalence of endoparasites found in birds of the genus Crax (Table 3) is corroborated by the data of MariettoGonçalves (2006), who also observed mixed parasite infections.

The authors referred to above, studying endoparasite prevalence in faecal samples of wild birds, also recorded the eggs of Ascaridia sp. and Capillaria sp. and the cysts of 
Table 1. Positive coproparasitological exams of cracids by species

\begin{tabular}{|l|c|c|c|c|c|}
\hline Species & Strongyloides sp. & Ascaridia sp. & Capillaria sp. & Entamoeba. coli & Strongyloidea eggs \\
\hline Ortalis guttata & + & - & - & - & + \\
\hline Penelope superciliaris & + & - & - & - & - \\
\hline P. obscura & + & - & + & - & - \\
\hline P. jacquacu & + & - & - & - & - \\
\hline P. ochrogaster & + & - & + & - & - \\
\hline Pipile pipile cujubi & + & - & - & - & - \\
\hline P. pipile cumanensis & + & - & - & - & - \\
\hline P. jacutinga & + & - & + & - & + \\
\hline Crax pauxi & + & + & - & - & - \\
\hline C. fasciolata fasciolata & + & + & + & - & - \\
\hline C. fasciolata pinima & - & + & - & - & - \\
\hline C. alector alector & + & - & - & - & - \\
\hline C. alector erythrognatha & - & - & - & - & - \\
\hline Crax blumenbachii & + & + & - & - & - \\
\hline C. daubentoni & + & - & - & - & + \\
\hline C. rubra rubra & + & - & - & - & + \\
\hline C. globulosa & + & + & - & - & - \\
\hline C. alberti & + & - & - & - & - \\
\hline Mitu tomentosa & - & - & - & - & - \\
\hline M. tuberosa & & - & - & - & - \\
\hline Nothocrax urumutum & - & - & - & - \\
\hline
\end{tabular}

Table 2. Prevalence of endoparasites by cracid genera

\begin{tabular}{|l|c|c|c|}
\hline Genera & $\mathrm{T}$ & $\mathrm{P}$ & $\begin{array}{c}\text { Prevalence (\%) } \\
\text { of positive samples }\end{array}$ \\
\hline Ortalis & 4 & 2 & 50.0 \\
\hline Penelope & 16 & 5 & 31.2 \\
\hline Pipile & 12 & 7 & 58.3 \\
\hline Mitu & 8 & 1 & 12.5 \\
\hline Crax & 40 & 16 & 40.0 \\
\hline Nothocrax & 4 & 0 & 0 \\
\hline
\end{tabular}

T: total analyzed faecal samples. P: positive samples

Table 3. Prevalence of endoparasites (\%) in different genera of cracids

\begin{tabular}{|l|c|c|c|c|c|}
\hline Genera of cracids & Strongyloides sp. & Ascaridia sp. & Capillaria sp. & Entamoeba coli & Strongyloidea eggs \\
\hline Ortalis $(\mathrm{T}=4)$ & $50.0 \%(2 / 4)$ & - & - & - & $50.0 \%(2 / 4)$ \\
\hline Penelope $(\mathrm{T}=16)$ & $18.8 \%(3 / 16)$ & - & $6.3 \%(1 / 16)$ & - & - \\
\hline Pipile $(\mathrm{T}=12)$ & $50.0 \%(6 / 12)$ & - & $16.7 \%(2 / 12)$ & - & $8.4 \%(1 / 12)$ \\
\hline Crax $(\mathrm{T}=40)$ & $25.0 \%(10 / 40)$ & $15.0 \%(6 / 40)$ & $2.5 \%(1 / 40)$ & $2.5 \%(1 / 40)$ & $7.5 \%(3 / 40)$ \\
\hline Mitu $(\mathrm{T}=8)$ & - & $12.5 \%(1 / 8)$ & - & - & - \\
\hline Nothocrax $(\mathrm{T}=4)$ & - & - & - & - & - \\
\hline
\end{tabular}

$\mathrm{P} / \mathrm{T}=\mathrm{P}$ : positive samples; $\mathrm{T}$ : analyzed faecal samples total

Entamoeba sp. along with the eggs of Heterakis sp., cysts of Balantidium sp. and Blastocystis sp., and the oocysts of coccidia, of which $17 \%$ of samples testing positive showed mixed parasite infestation. These authors observed that, of the 12 orders of birds analyzed, only five tested positive. Coccidia were the parasites most commonly encountered, principally in the order Passeriformes. 
The data given by Freitas et al. (2002) and Marietto-Gonçalves (2006) differ slightly from those given here because those authors did not find oocysts of coccidia. The absence of oocysts of Eimeria sp. and Isospora sp. in the cracids of the present study could have been due to two scenarios: hygiene protocols with appropriate treatment for worming against coccidia but inefficient for other endoparasites, and the fact that, following infection by coccidia the birds develop a level of immunity, even though immunogeneric stages vary according to species. It is known that these mechanisms of immunological response in the face of endoparasitic infection happen as a result of a combination of humoral and cellular immune responses. However, they are not well known in wild birds (Urquhart et al. 1990).

Marietto-Gonçalves (2006) reported that coccidia were the commonest parasites in their analyses on birds. However, it is worth pointing out that in that study $95.45 \%$ of the samples testing positive came from Passeriformes. There were no coccidia found during this study.

Goulart et al. (2005), analysing the results of endoparasite occurrence in captive-bred wild bird species bred in different enclosures, observed that those found were protozoa and nematode worms; apart from one result involving heteroxenous parasites (indirect life cycle).

Bolochio et al. (2002) carried out a study on the casuistry of endoparasites in wild birds in the collection at the Guarulhos Municipal Zoological Garden (Zoológico Municipal de Guarulhos), São Paulo and reported that, of the 33 exams testing positive in these birds, $8(24 \%)$ were positive only for nematodes, in this case including Capillaria sp., Ascaridia sp. and Strongyloides sp. Of the most prevalent, 14 (43\%), positive results were obtained for coccidia only, including Caryospora and Isospora as the most frequent genera, and $11(33 \%)$ for coccidia and nematode worms simultaneously. This divergence in results is probably due to behavioural differences between Passeriformes and cracids.

This being so, Goulart (2005) went on to state that the prevalence of endoparasites in birds occupying terrestrial enclosures was substantially higher than the prevalence of endoparasites in birds from suspended enclosures. In this study, of the samples collected from Cracid enclosures having a floor substrate exclusively of sand, 33.3\% tested positive for Strongyloides sp., Ascaridia sp., Entamoeba coli and Balantidium cysts.

The results presented here reinforce the data reported in Goulart (2005), who state that Tinamiformes (tinamous and allies), being ground-level feeders, as are the Galliformes, are more susceptible to constant reinfection by endoparasites. Members of the Psittaciformes (macaws, parrots, parakeets, cockatoos and allies) which feed from suspended food sources and not usually at ground level are, therefore, less susceptible.

The presence of eggs of Ascaridia sp. has already been reported in the orders Galliformes. Eggs of Capillaria sp. have also been recorded in the faeces of the orders Galliformes and Passeriformes (Marietto-Gonçalves 2006). Such data corroborate the results presented here, because eggs of Ascaridia sp. and Capillaria sp. were identified. Nevertheless, eggs were not recorded for Heterakis sp. It is known that Heterakis sp. is a nematode considered as non-pathogenic. However, its importance is connected to the spreading of the protozoan Histomonas meleagridis which causes avian blackhead disease. The presence of adult roundworms of both genera is important in veterinary medicine because they can cause intestinal disturbances such as enteritis and haemorrhaging (Urquhart et al. 1990; Vasconcelos 2000).

The presence of cysts of Entamoeba coli as described here is corroborated by the results of Bolochio et al. (2002), Freitas et al. (2002), and Evêncio-Neto (2006) who identified the same endoparasites in wild birds. The pathogenicity of Entamoeba coli in birds is uncertain, although it is known that $E$. coli has zoonotic qualities (Kemp 1978; Yoshikawa et al. 2004) and can affect professionals such as veterinarians, biologists, and zookeepers who work with birds. 
In the animals infected by coccidia clinical symptoms manifested included bouts of diarrhoea, apathy, a lowering in posture, loss of weight and death (Kawazoe 2000). These disturbances were identified by Bolochio et al. (2002), Goulart (2005) and MariettoGonçalves (2006). The absence of signs and symptoms involving disturbances to the gastrointestinal and respiratory system in the birds analysed in this study corroborate the negative results for Caryospora sp., Eimeria sp. and Isospora sp.

It is worth pointing out that infections occur in wild birds kept in captivity principally because of poor standards of hygiene and sanitation arising from the introduction of new stock without first undertaking quarantine controls or coproparasitological examinations which would otherwise help in assessing the condition of birds. The carrying out of periodical examinations enables the monitoring of the health status of stock and the adoption of suitable measures for the control of endoparasites, avoiding massive outbreaks of infestation and their consequences, which can include death.

In conclusion, the endoparasitical infection in Cracidae wild avian bred in captivity at the Parque Dois Irmãos was constituted by Strongyloides sp., Ascaridia sp., Capillaria sp., Entamoeba coli and Strongyloidea eggs.

\section{Prevalence výskytu endoparazitů ve vzorcích stolice hokovitých ptáků chovaných v zajetí v parku Dois Irmãos, Recife, Pernambuco, Brazílie}

$\mathrm{Z}$ mnoha problémů vyvstávajících z nízké úrovně hygieny v prostorách, kde jsou chováni ptáci, jsou nejčastější parazitární infekce. Jejich průběh může být subklinický až smrtelný. Jedním z nejčastějších případů jsou endoparazitární infekce, zejména $\mathrm{v}$ př́ípadech, $k d y$ žije velké množství jedinců na jednom místě. Vzhledem k této skutečnosti bylo cílem této práce zjistit prevalenci endoparazitů ve vzorcích trusu hokovitých ptáků (hoko a př́buzní) chovaných v zajetí v parku Dois Irmãos, Recife, Pernambuco v Brazílii. Za tímto účelem byly sbírány vzorky trusu z výběhů ptáků z čeledi hokovitých patřících do fondu parku Dois Irmãos, kteři původně pocházeli ze soukromých chovů metropolitní a lesní oblasti státu Pernambuco. Ćtyři soubory vzorků trusu a písku byly sbírány po dobu 60 dnů, čímž se ve výsledku získalo 84 vzorků trusu od 58 jedinců 21 druhů hokovitých. Získané vzorky byly koprologicky testovány metodou spontánní sedimentace a "right method". V získaných vzorcích byly detekovány Strongyloides sp. Ascaridia sp. Capillaria sp. a cysty Entamoeba coli, stejně tak jako oocysty nadčeledi Strongyloidea.

\section{References}

BARNES HJ 1986: Parasites. In: HARRISON GJ, HARRISON LR (Eds.): Clinical avian medicine and surgery. W. B. Saunders Company, Philadelphia, pp. 472-485.

BENEZ SM 2004: Aves: criação, clínica, teoria, prática, silvestres, ornamentais, avinhados. Tecmedd, São Paulo, $600 \mathrm{p}$.

BOLOCHIO CE, IGAYARA-SOUZA CA, ASSATO EH, NAGAHAMA AA, CUNHA IP 2002: Casuística dos exames protoparasitológicos realizados no zoológico municipal de Guarulhos, SP. In: Anais do XI. Congresso Paulista de Zoológicos, São Paulo, Brazil

COUTO D 1997: Correlações ecológicas entre ectoparasitas e aves de florestas de Minas Gerais. In: LEITE LL, SAITO CH (Eds.): Contribuição ao conhecimento ecológico do cerrado. Departamento de Ecología, Universidade de Brazília, pp. 210-218

EVÊNCIO-NETO J 2006: Galliformes (Mutum, Jacu, Jacutinga, Aracuã, Uru). In: CUBAS ZS, SILVA JCR, CATÃO-DIAS JL (Eds.): Tratado de animais selvagens: medicina veterinária. Roca, São Paulo, pp. 169-184

FREITAS MFL, OLIVEIRA JB, CAVALCANTI MDB, LEITE AS, MAGALHÃES VS, OLIVEIRA RA, EVÊNCIO-SOBRINO A 2002: Gastrointestinal parasites of captive wild birds in Pernambuco state, Brazil. Parasitol Latinoam 57: 50-54

GOULART CES 2005: Ocorrência de endoparasitos em aves silvestres em diferentes recintos no Vale Verde Parque Ecológico. In: Anais da $5^{\text {a }}$ Conferência Sul-Americana de Medicina Veterinária, Rio de Janeiro, Brazil

GREVE JH, SAKLA AA; MCGEHEE EH 1978: Bilharziasis in a Nanday conure. J Am Vet Med Assoc 172: 1212-1214

KAWAZOE U 2000: Coccidiose. In: BERCHIERI JR A; MACARI M (Eds.): Doenças das aves. Editora Facta,Campinas, pp. 391-401 
KEMP RL 1978: Trichomonads, other flagellates, and protozoa. In: HOFSTAD MS, CALNEK BW, HELMBOLDT CF, REID WM, YODER HW, Jr (Eds): Diseases of poultry. $7^{\text {th }}$ ed. The Iowa State University Press Ames, Iowa, pp. 841-846

KRANTZ GW 1970: A manual of acarology. Oregon State University Book Stores Inc., Corvallis, 335 p.

MACHADO IC, LOPES AV, PÔRTO KC 1998: Reserva ecológica de Dois Irmãos: estudos em um remanescente de Mata Atlântica em área urbana (Recife-Pernambuco-Brasil). Universitaria of UFPE, 326 p.

MARIETTO-GONÇALVES GA, MARTINS TF, DE LIMA ET, LOPEZ RS, FILHO RLA 2006: Prevalência de endoparasitas em amostras fecais de aves silvestres e exóticas examinadas no laboratório de ornitopatologia e no laboratório de enfermidades parasitárias da FMVZ-UNESP/Botucatu-SP. In: XV. Congresso Paulista de Zoológicos, São Paulo, Brazil

RITCHIE B, HARRISON GJ, HARRISON LR 1994: Avian medicine: principles and application. Wingers Publishing, Florida, 1384 p.

SCHOLTENS RG, NEW JC, JOHNSON S 1982: The nature and treatment of giardiasis in parakeets. J Am Vet Med Assoc 180:170-173

URQUHART GM, ARMOUR J, DUNCAN JL, DUN AM, NENNINGS FW 1990. Parasitología Veterinária. $2^{\text {nd }}$ ed. Guanabara Koogan, Rio de Janeiro, 273 p.

VASCONCELOS OT 2000: Parasitoses em aves de produção industrial. In: BERCHIERI Jr A, MACARI M: Doenças das aves. Editora Facta, Campinas, pp. 423-428

YOSHIKAWA H, MORIMOTO K, WU Z, SINGH M, HASHIMOTO T 2004: Problems in speciation in the genus Blastocystis. Trends Parasitol 20: 251-255 